\title{
L'ultra-distanza e l'epifenomeno della finitezza, tra distanza e Distanza
}

Rosario Giovanni Brandolino

Paola Raffa

Abstract

Prima lo sguardo e poi la parola, in questo senso la larghezza, la lateralità e la distanza portano a immaginare una moltitudine di orizzonti alternativi. Alcune distanze sono considerazioni che appaiono quando si sente che 'percepire' è un modo di esaminare e di interrogarsi con gli occhi.

Le utopie consolano, afferma Paul-Michel Foucault, ed è quello che si può trarre dalla Iconic Artworks di Marina Abramovic. La The House with the Ocean View, è una installazione pubblica vivente, una sorta di isolario domestico che un'artista seminale pone in una suddivisione di stanze. Dodici giorni in tre ambienti sopraelevati, due vani e un servizio, diventa lo scenario di una visione esperenziale e apocalittica di una routine quotidiana, con regole e restrizioni. L'impossibilità di uscire, prossemica clausura di una attuale quarantena in lockdown, manifesta nei collegamenti verticali, scalette di coltelli, le analogie con una esistenza pubblica confinata.

Parole chiave

distanza, estetica dello sguardo, immagini, disegno, utopia.

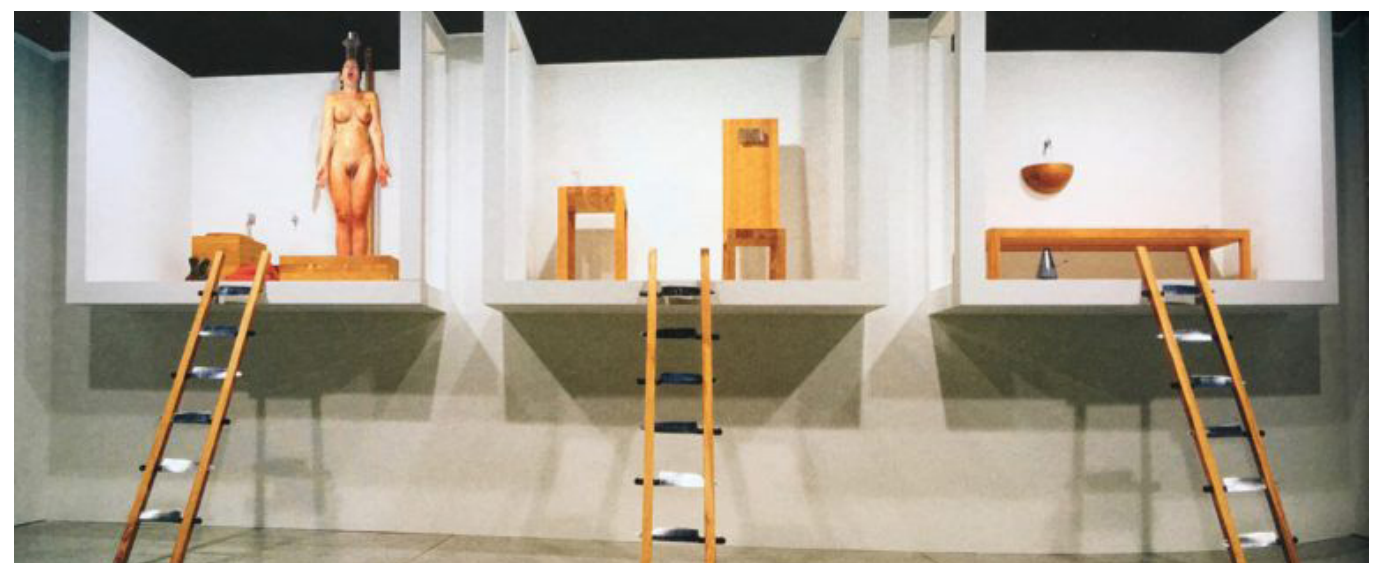


Le distanze non separano lo sguardo dalle osservazioni che si associano alle diversità del disegno per tipologia di veduta, per esplorazione della visione, per posizione di un punto strategico che è contrassegnato dall'ampiezza di uno scatto angolare.

Ambiente, contesto e piano rappresentano una relazione percettiva tra uno spazio di prossimità e uno spazio di lontananza nell'evocazione di un luogo fissato, un contatto visivo come contenitore di immagini.

Lo sguardo che viene definito appartiene a un ordine prefissato delle distanze che, tra collocazione e spostamento, esercita essenziali punti di appoggio, che stabiliscono un intorno tra misura e dismisura.

Prima lo sguardo e poi la parola, in questo senso la larghezza, la lateralità e la distanza nel disegno portano a immaginare una moltitudine di orizzonti alternativi.

Il disegno è descritto tra lo strofinio di un'istante e la distanza di un'immagine sul paesaggio di grafite, che risiede nei disegni d'occasione, rimane natura messa in posa, tra segni reinterpretati e argomenti che attingono alla necessità di una traccia.

Alcune distanze alla definizione di un 'disegnare è correggere', di un 'disegnare è capire', sono considerazioni che appaiono quando si sente che 'percepire' è un modo di esaminare e di interrogarsi con gli occhi.

In fondo, la distanza è la scena della rappresentazione. È ciò che rimane e si riporta in presenza quando, spesso, di fatto, è sparita la presenza. Disegnando, in assenza della distanza, si trae il luogo in cui ogni presenza diviene lettura della misura, dello spazio, della forma osservata.

Le diversità di un insieme che divide due nessi con i termini di 'distanza' e 'Distanza' rappresentano tutto ciò che si relaziona tra noi e il nostro intorno, qualcosa che diviene un intermezzo variabile. Ciò che la visione unisce, tra una cesellatura e l'immenso.

Immaginari egemoni.

Fig. I. Emilio Tadini, La camera da letto, 1993.

Fig. 2. Emilio Tadini Oltremare, 1992.
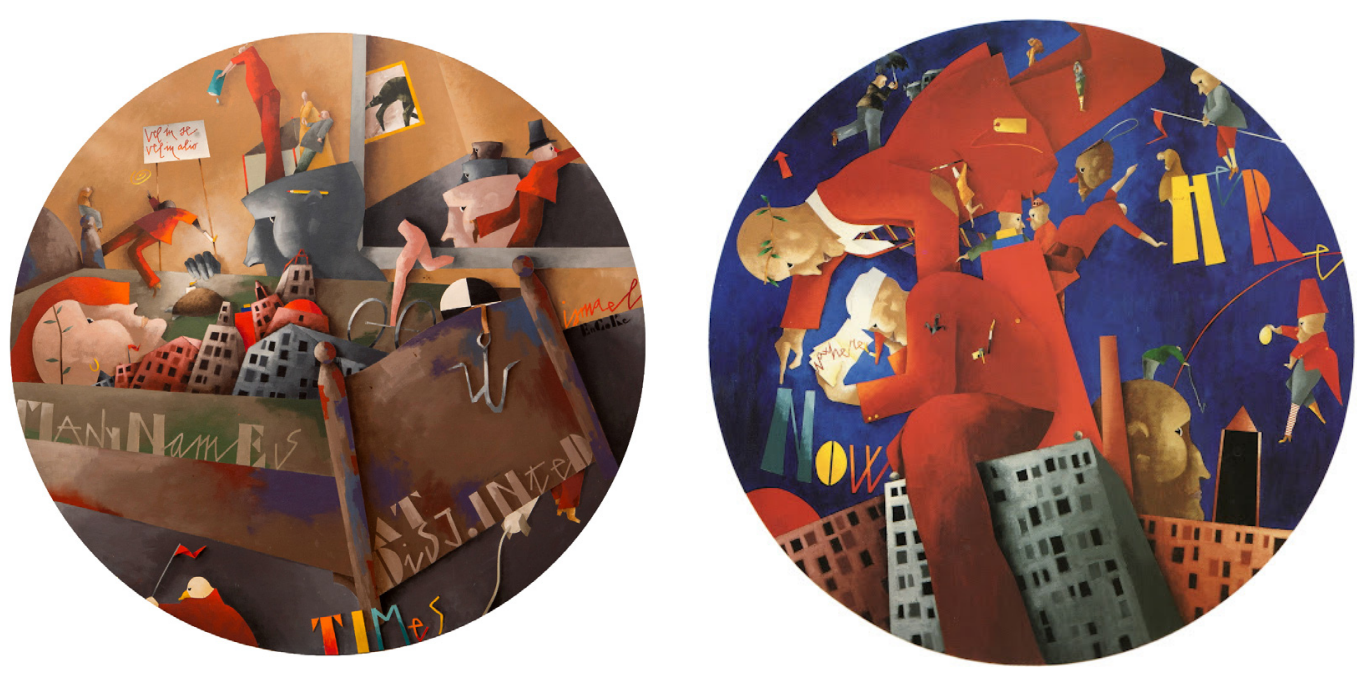

II mondo a caso pone

[Epicuro]

La Distanza come valore di un enigma ci accomuna nelle ipotesi e approssimazioni che Emilio Tadini ripone nell'evidenza di una soffice e duttile fragilità in cui rappresentazione, forma e, forse, tutto ciò che noi chiamiamo 'estetico', si pongono l'obiettivo di misurare la distanza [Tadini 1998, pp. I-9]. 
In una nota di riflessione, nel pathos della 'distanza', Italo Calvino afferma che non è la 'distanza', ma la passione per l'inaudito che pone il concetto di separatezza. Tutto ciò che si ripone nel distanziarsi nell'immaginario tra immanenza e distanza, così come avviene in un racconto: "Lo so bene - esclamò il vecchio Qfwfq - voi non ve ne potete ricordare ma io sì. L'avevamo sempre addosso, la luna, smisurata" [Calvino 1965]. Calvino pone la distanza nella descrizione onirica di una luna distanziata ma non distante, in un rapporto metaletterario di conflittualità espressiva.

Tra i poeti lunari il concetto di 'distanza' muove da alcuni versi dell'Ariosto che, sulla luna di Astolfo, nel momento in cui si rende conto delle dimensioni mutevoli, pone il rovesciamento di uno sguardo:"Qui ebbe Astolfo doppia meraviglia: che quel paese appresso era sì grande, il quale picciol tondo rassomiglia a noi che lo miriam da queste bande; e ch'aguzzar convegli ambe le ciglia, s'indi la terra e 'I mar ch'intorno spande, discerner vuol; che non avendo luce, l'imagin lor poco alta si conduce" [Ariosto 1982, XXXV, 7I].

Fig. 3. Luca Ronconi, con la trasposizione di Er Ando Furioso di Ludovico Ariosto, 1969 rasposizione teatrale del poema dell'Ariosto messa inscena nell'estate del 1969 al Festival de due Mondi di Spoleto.

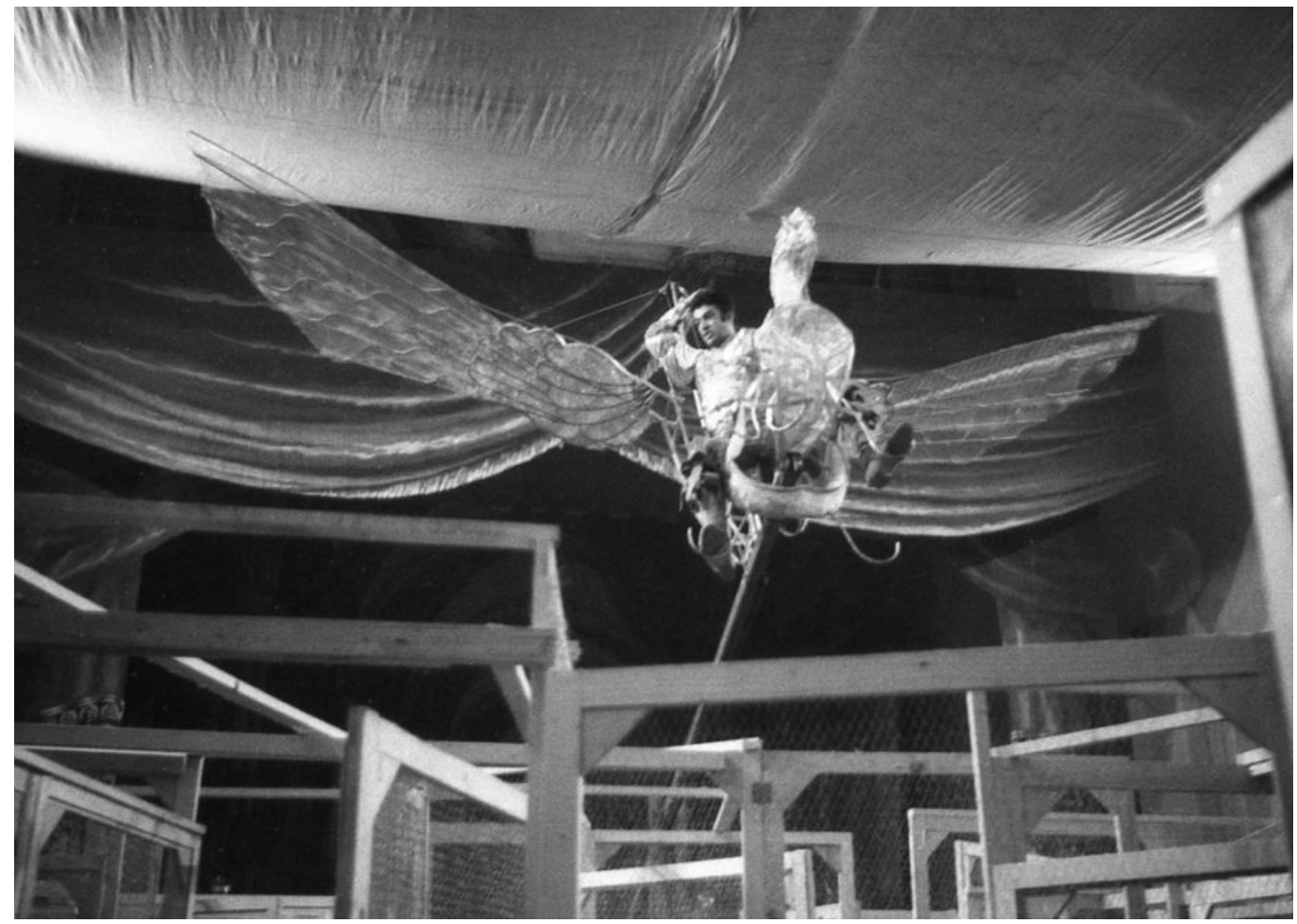

Tra la luna e l'isole remote appare il rovesciamento della distanza che due pianeti assumono cambiando il punto di osservazione e l'enigma del comporre misteriose facies nella visione di un topos sostituendo nell'ignoto punti e lettere di una filigrana per l'interpretazione astratta di un atlante.

L'importanza sulla distanza che appare di un 'disegno smarrito' appartiene alle considerazioni di Judith Schalansky [Schalansky 2009], tra isole e insulari, in cui si descrive del vagare con le dita di una mondografia e del dilatato senso di utopia, lontano da tutto e da tutti in una distanza che pone il cartografo nel luogo in cui la terra non ha margini.

Non distante dalle suddette utopie vi è anche la visione immaginifica del ripercorre, in uno smisurato contesto planetario, distanze oscure nel racconto dei luoghi di Fra' Mauro che, nelle meditazioni di un cartografo, traccia i confini di terre mai viste. Dai racconti di esploratori, mercanti, missionari e pellegrini in terre lontane, intraprende con l'immaginazione, su pergamena, una rappresentazione ideale soggettiva di una ispirazione di inattesi interrogativi nel sogno di disegnare il mondo [Cowan 1998]. 
Fig. 4. Judith Schalansky, Atlante delle Isole remote. Cinquanta isole dove non sono mai stata e mai andrò, 2013.
Fig. 5. Fra Mauro, Mappamondo XV secolo, 450 c. (dettaglio), Marioteca Nazionale Marciana, Venezia).

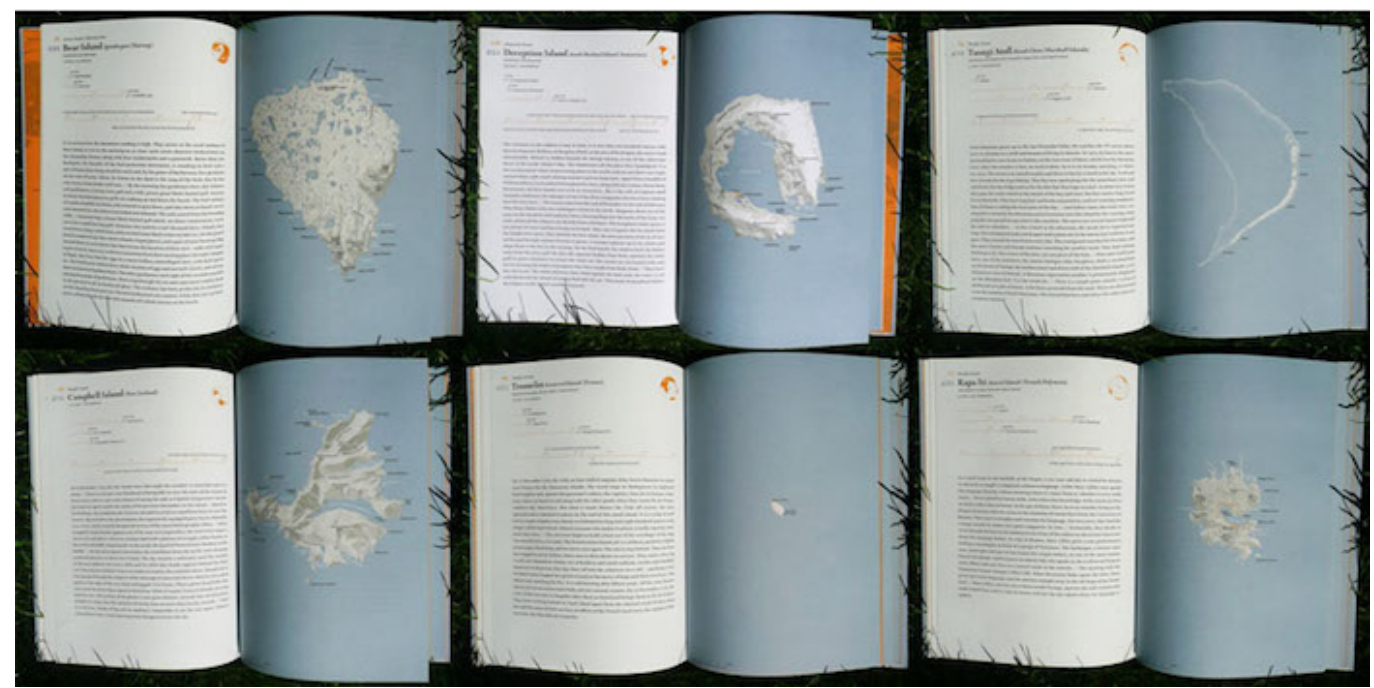

Ulteriori traiettorie della distanza, tra storie e utopia, sono i disegni-collage [Baglivo 20 I 4] di un immaginario-concettuale, una visione singolare di distanze senza tempo in sconfinamenti, montaggi e mutazioni nella rappresentazione di un aspetto introspettivo di una riscrittura circolare, tra il monumento e l'innesto.

Ed ancora, John Berger afferma che disegnare è un modo di indagare [Berger 20l I], è la condizione che appare tra le pagine ritrovate di un taccuino, attribuito al filosofo olandese Baruch Spinoza, detto Bento, annotando che nell'osservare con gli occhi altrui vi è il senso delle cose.

La distanza che si affronta, nel taccuino di Bento, pone sull'atto dello sguardo che in ogni "disegno di simulazione" appare la distanza di un processo creativo tra il reale e l'immaginario. Nell'atto di guardare, di interrogare gli occhi siamo quasi diventati intercambiabili.

Deve essere perché entrambi sappiamo dove e a cosa può condurre la pratica del disegno e nel tout se tient, tutto si adatta. "Disegnando parti da te, ma lo sforzo è diventare ciò che stai guardando. Cogliere il collegamento con la cosa che hai davanti e quelle intorno, che non si vedono in una forma di contemplazione manuale" [Berger $20 \mathrm{ll}$ ].

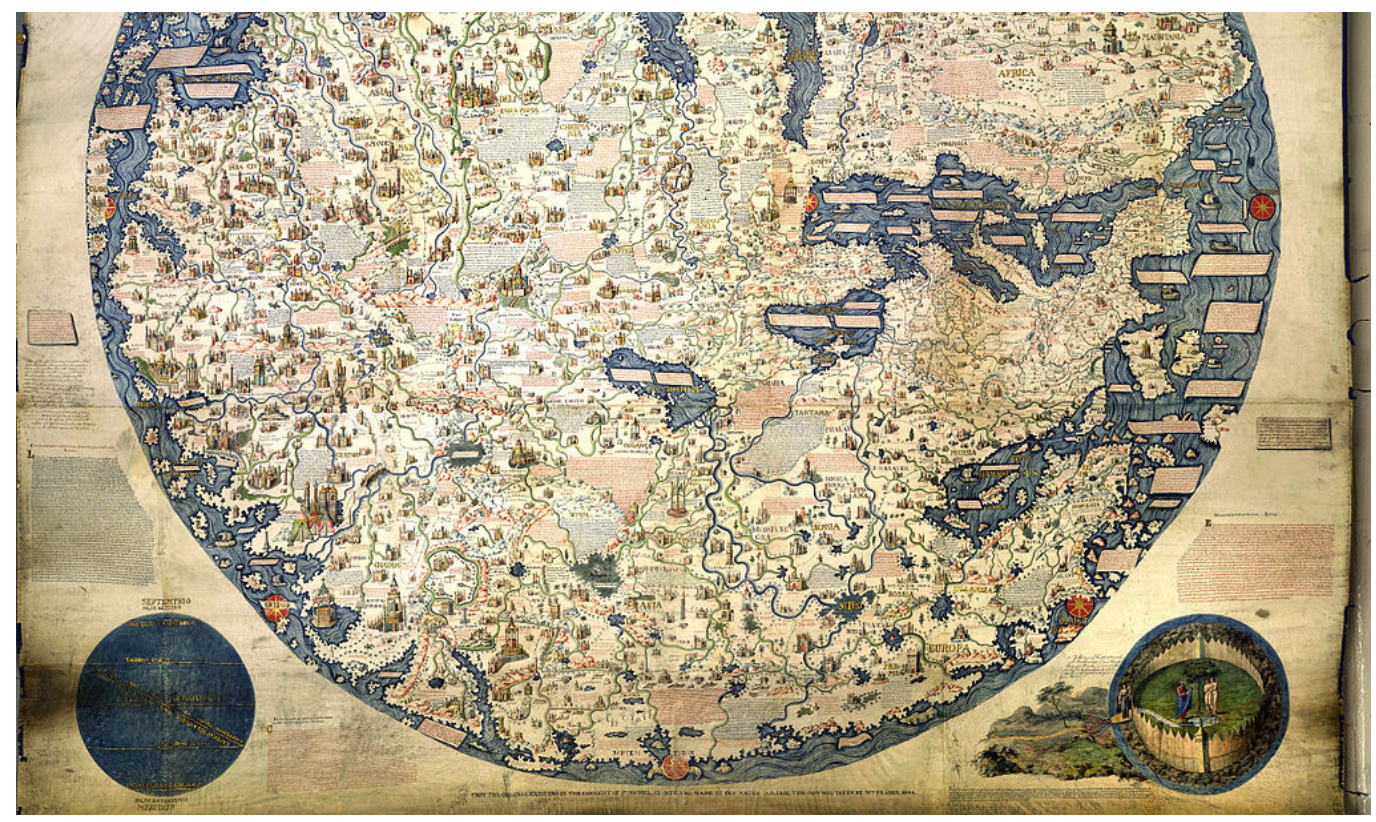




\section{Utopie del distacco}

L'utopia è un disegno etico, distante dal ritrovare un'"'isola che ammette la passione e rifiuta le illusioni"' [Overton 20 I8].

Tra gli aspetti di un'utopia solidale appare l'esperienza di Soul City, North Carolina, dalla costruzione utopica alla città prigione 1970-1997, che non riguarda storia ispirazionale, ma essenzialmente una "Città Negra", una città mai nata. La distanza ideale che si avvale di un sogno spezzato, metafora per i neri d'America di una terra degli uomini liberi alla delusione dell'ultima utopia del distacco è il divenire degli esclusi, rimane la distanza di un tentativo per una possibile integrazione svanita per "Soul City: race, equality, and the lost dream of an american utopia" [Grosso 202I].

La distanza oculare di un'utopia appare anche tra distrofie e infermità, in patologie del buio o della diversità ed è quella che si compone in strofe. Riguarda la storia di Dippold, poesie e confessioni in forma di epitaffio [Lee Master 1943].

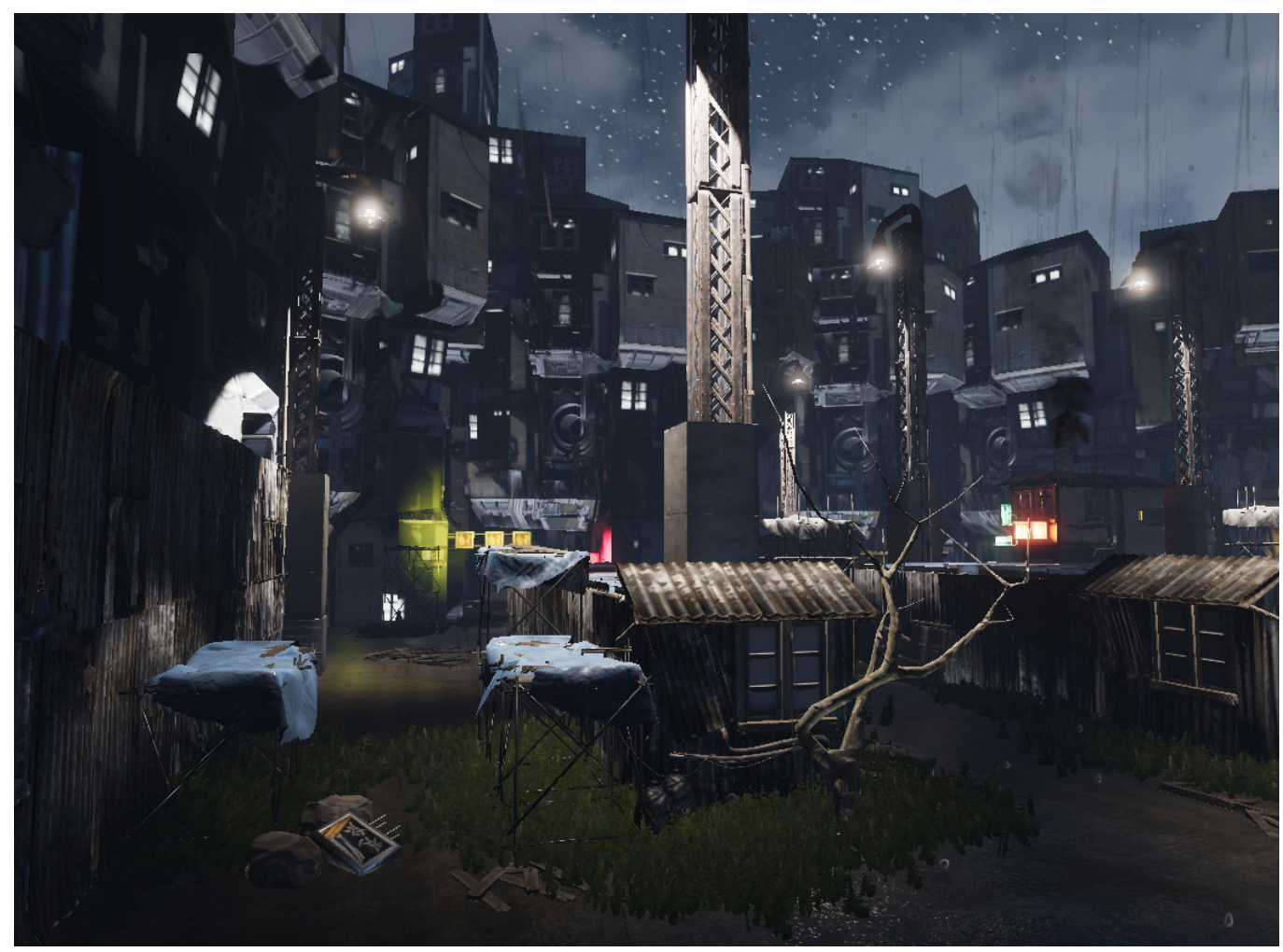

Nel racconto di un ottico che, nell'idea di ottimizzare la distanza, stanco di far vedere ai clienti semplicemente cosa sta loro intorno, che vuole fare occhiali speciali che aiutino a vedere oltre la realtà. Versi che Fabrizio De André, su Un ottico ricompone la traccia di un frammento: "Daltonici, presbiti, mendicanti di vista il mercante di luce, il vostro oculista, ora vuole soltanto clienti speciali che non sanno che farne di occhi normali. Non più ottico ma spacciatore di lenti per improvvisare occhi contenti, perché le pupille abituate a copiare invertino i mondi su quali guardare. Seguite con me questi occhi sognare, fuggire dall'orbita e non voler ritornare" [De Andrè 197I].

In fondo, la distanza è proprio quella luce che trasforma il mondo in un giocattolo. 


\section{Utopie del dialogo visivo}

Nell'immobilità si può riconoscere il movimento ed è la connessione che esercita Marina Abramovic [Akers 20 I2], al MoMA di NY nel 20 I0, dove la distanza costante trova meno spazio per andare altrove. Una performance che unisce le linee orizzontali dello sguardo di un dialogo visivo di oltre 750.000 persone nell'invariabile lunghezza che si trova in un rapporto silente del comunicare. Estendere lo spazio in una doppia interminabile linea nelle 736 ore di una univoca presenza e stabile distanza del connettere, toccare l'estremo, in quel flusso di energia che non ha più bisogno di nulla.

Sguardi attraverso sguardi sono le sensazioni che appartengono alla stessa distanza immateriale, su un filo invisibile, che descrive attraverso le opere la partecipazione di chi viene "osservato". Le tele contengono 'trappole iconografiche' che delineano l'aspetto informale della distanza tra il dipinto e l'osservatore [Corgnati 20 I I]. Un sistema di sguardi interni posto nei dipinti dei personaggi che guardano la relazione di una visibilità dell'essere osservante e osservato sulla distanza di un artificio del guardare per essere guardati tra gli sguardi dei telai su l'osservatore dirimpetto e l'inquadratura del soggetto in risvolti tematici.

I monumenti ci guardano dall'alto e tutto ciò che appartiene a una percezione inclinata dello sguardo, come Sigmund Freud afferma "la sensazione dominante, il primo impatto con la statua, concerne il senso di immobilità cui segue la percezione della fissità dello sguardo dell'occhio di pietra. Se le statue sono più d'una si instaura poi un intreccio di sguardi su imprevedibili traiettorie" [Barucchello 2003]. Lo sguardo di pietra, di marmo e ligneo ricompongono l'immobilità percettiva descritta da Andrei Arsenyevich Tarkowskij di 'scolpire il tempo' [Tarkovskij 2002] figure di una dimora stanziale in cui lo sguardo intreccia orientamenti stabili nella spazialità di un luogo in relazione alla cecità della materia.

E nella consapevolezza di possedere grandi occhi, vi è una visione elastica in Margaret Keane, in una consolidata prerogativa che riguarda lo sguardo. In quasi tutte le opere i personaggi hanno grandi occhi spalancati e perfettamente circolari, che coprono una considerevole parte del viso, introiettando l'osservatore in un mondo parallelo.

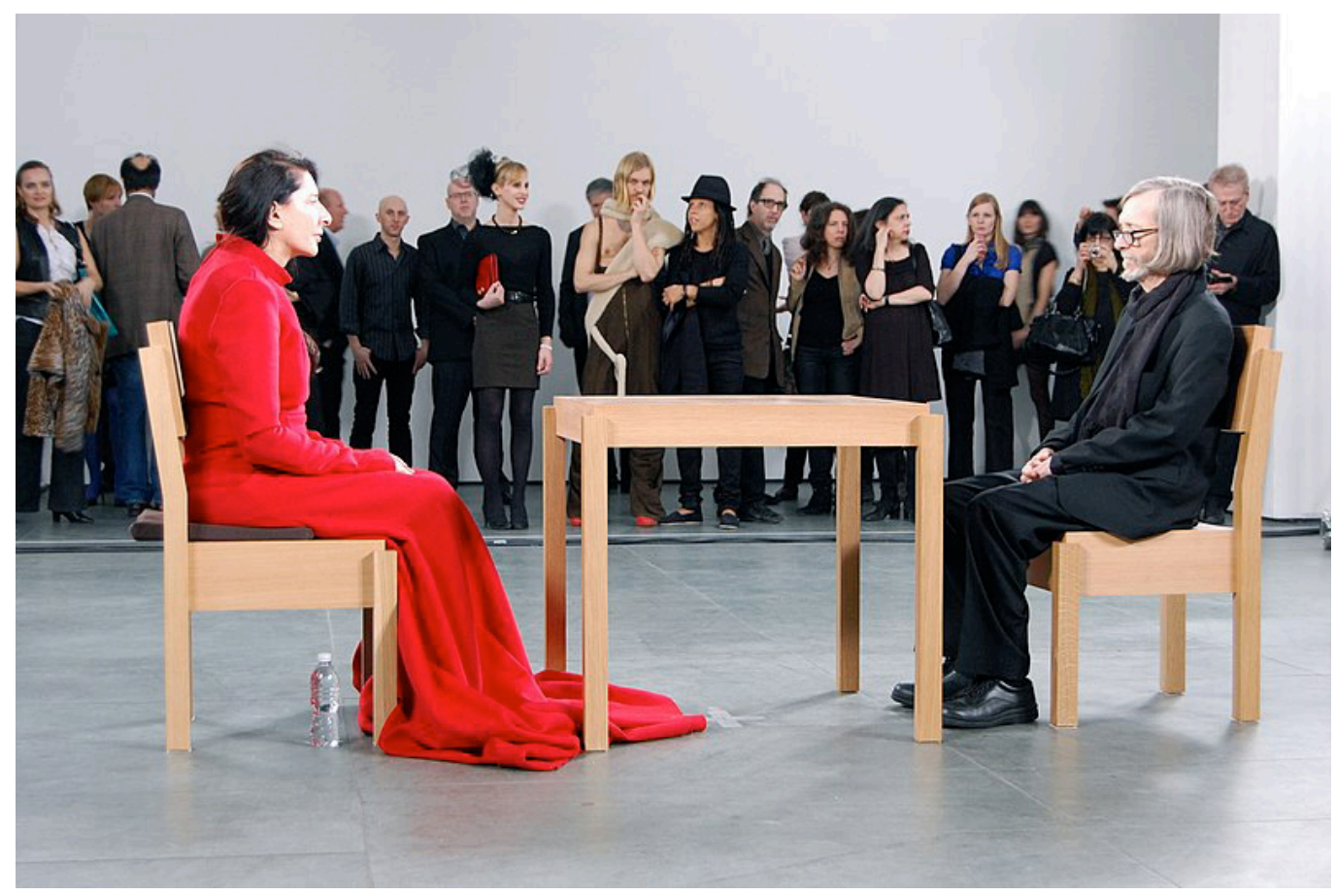


In Big Eyes, un film diretto da Burton nel 20I4, si ritrae la distanza inversa che esprime Margaret Keane nei ritratti infantili, in cui nelle figure rappresentate appare la misura dello sguardo e i grandi occhi esprimono la distanza interiore di un ampio dialogo visivo.

Fig. 7. Margaret Keane Big Eyes, 1963.

Fig. 8. Margaret Keane Big Eyes, 1981.
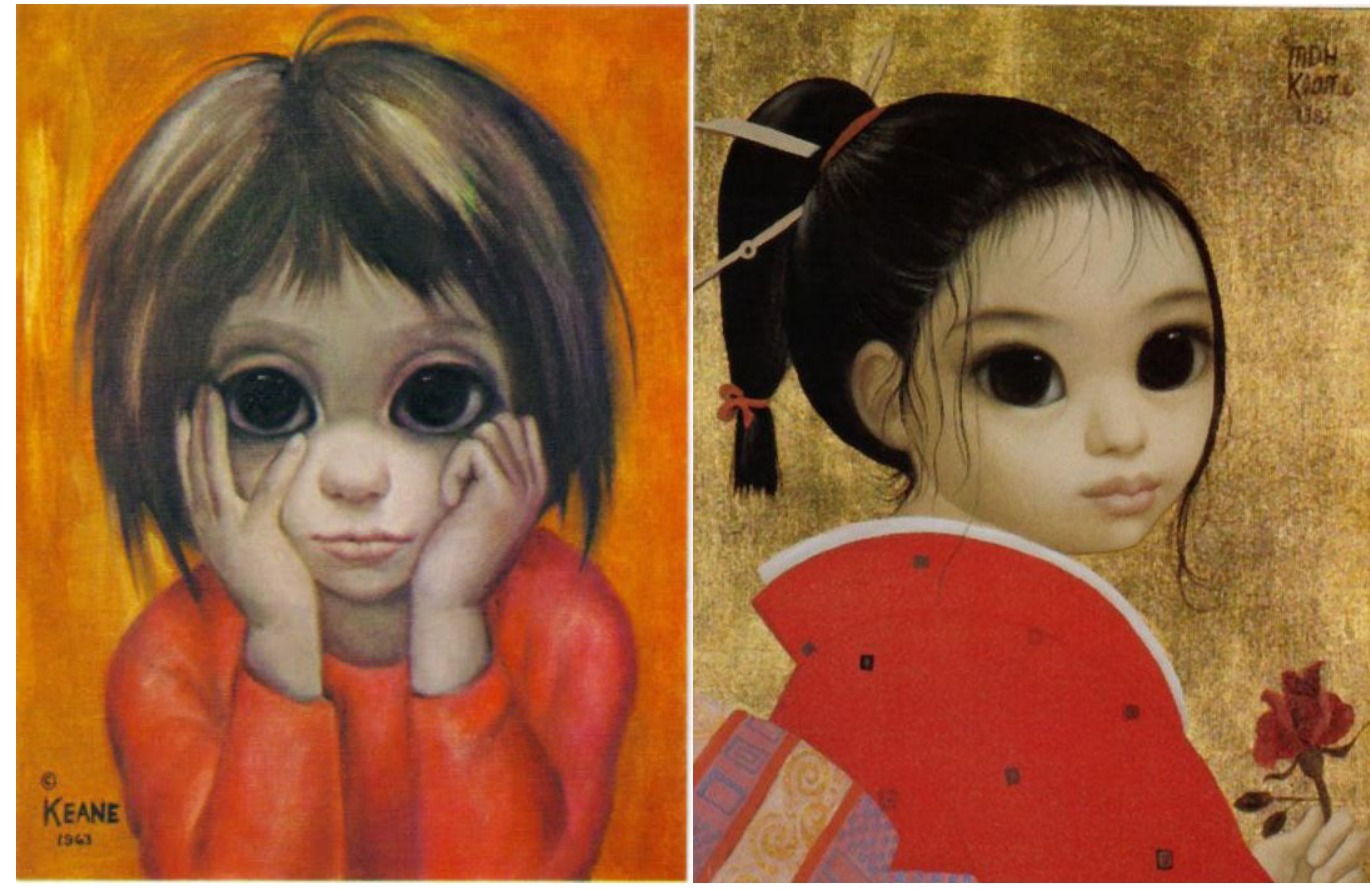

\section{Conclusioni}

Il prossimo è distanza sullo stesso piano [Emilio Tadini]

Ambiguità e svelamento, fra un polo e l'altro, tra vicinanza e distanza, al limite di qualsiasi sguardo risiede una relazione di prossimità che diviene relazione di equilibri.

Una finalità sostanziale è individuata nel tentativo di argomentare una forma espositiva discretizzata, per punti, che corrispondono alla denominazione delle 'mappe' interlocutorie in cui la distanza non può che presentarsi come una nuova immagine del reale.

Lo spazio, quindi, diviene la rappresentazione di incontro fra ciò che appare e lo sguardo condiviso, un abitare l'estraneità da immaginari eccedenti che riguardano una relazione nell'unità di vicinanza e distanza.

In questo contesto, oltreconfine, sono considerabili i fenomeni di venuta e comparsa dei dislocamenti migratori, una geografia dello sguardo sequenziale che cerca di capire la complessità dello spazio dinamico, flussi di diversa natura, relazioni multidimensionali della visione continua per identificare, ricomporre, trascrivere i segni di una logica di riduzione nel guardare, graduare e comporre le linee di classificazione e significati ai segni che connotano la mobilità umana con il ruolo dell'immagine del 'pensiero visivo' e dello 'sguardo perduto'. A tal fine, si compongono altre mappe di migrazione umana su uno 'sguardo continuo' determinando ciò che allude 'geografie difficili' della distanza e ai luoghi neutri e dello 'sguardo ospitale'.

Spazi di convivenza in distanza sono le visioni distopiche di un comportamento virtuoso, forzati cambiamenti temporanei dell'essere confinato, con un social distancing con spazi di controtendenza. 
Uno 'sguardo di mutazione' verso una ricerca di dispersione è quella di spaesamento che appare nel paesaggio dell'incertezza, una fragile sospensione nel mantenere la distanza di una Distanza, una forma di abitudine di relativismo oculare.

Lo schermo contrae lo spazio diluito come forma di comunicazione sociale, la visione è un'eccezione del contagio, un ideale stato di separazione, una percezione pervasiva della distanza.

La percezione ha il contagio di luogo stabile per cogliere l'assoluto, mediante forme sensibili in cui lo sguardo diviene la rubrica di ciò che ci appare e la diffidenza di fondare la visione di un intus legere. Leggere la distanza unisce la connectografia dentro la visione insieme immagini, per incrociare gli sguardi tra uno spazio virtuale e l'estensione 'reale', nella percezione dell'infosfera di uno smisurato contesto.

In fondo, come afferma Emilio Tadini, tra distanze immense e distanze minime, ogni distanza è rappresentabile da un segmento di linea, misurabile in quanto limitato da due punti.

\section{Riferimenti bibliografici}

Akers M. (20|4). Marina Abramovic. The artist is present. Milano: Feltrinelli.

Ariosto L. (1982). Orlando Furioso. Milano: BUR.

Baglivo C. (20|4). Disegni corsari. Melfi: Libria.

Barucchello G. (2003). Cosa guardano le statue. Ravenna: Danilo Montanari.

Berger J. (20 I I). II taccuino di Bento.Vicenza: Neri Pozza.

Calvino I. (1965). Le Cosmicomiche. Torino: Einaudi.

Corgnati M. (20 I I). I quadri che ci guardano. Opere in dialogo. Bologna: Editrice Compositori.

Cowan J. (1998). Il sogno di disegnare il mondo le meditazioni di fra Mauro cartografo alla corte di Venezia. Milano: Rizzoli.

De Andrè F. (197I). Non al denaro, non all'amore né al cielo. Milano: Dischi Ricordi.

Grosso L. (202I). II sogno spezzato. Quel che resta di un'utopia. Soul City, la città dei adesso è soltanto una prigione. In L'Espresso n. 15, Roma 4 aprile 2021.

Lee Master E. ( 1943). Antologia di Spoon River (trad. Pivano F.). Torino: Einaudi.

Overton T., Nadotti M. (a cura di). (2018). John Berger. Ritratti. Milano: il Saggiatore.

Schalansky J. (2009). Atlante delle isole remote. Cinquanta isole dove non sono mai stata e mai andrò. Milano: Bompiani.

Tadini E. (1998). La distanza.Torino: Einaudi.

Tarkovskij A. (2002). Scolpire il tempo. Milano: Ubulibri.

\section{Autori}

Rosario Giovanni Brandolino, Università degli Studi Mediterranea di Reggio Calabria, gianni.brandolino@gmail.com Paola Raffa, Università degli Studi Mediterranea di Reggio Calabria, paola.raffa@unirc.it

Per citare questo capitolo: Brandolino Rosario Giovanni, Raffa Paola (2021). L'ultra-distanza e l'epifenomeno della finitezza, tra distanza e Distanza/Ultra-distance and the epiphenomenon of finitude, between distance and Distance. In Arena A., Arena M., Mediati D., Raffa P. (a cura di). Connettere. Un disegno per annodare e tessere. Linguaggi Distanze Tecnologie. Atti del $42^{\circ}$ Convegno Internazionale dei Docenti delle Discipline della Rappresentazione/Connecting. Drawing for weaving relationship. Languages Distances Technologies. Proceedings of the $42^{\text {th }}$ International Conference of Representation Disciplines Teachers. Milano: FrancoAngeli, pp. I 38 I- 1396. 


\section{Ultra-Distance and the Epiphenomenon of Finitude, between 'distance' and Distance}

Rosario Giovanni Brandolino

Paola Raffa

Abstract

First the look and then the word, in this sense the width, the laterality and the distance lead to imagine a multitude of alternative horizons. Some distances are considerations that appear when one feels that 'perceiving' is a way of examining and questioning oneself with the eyes.

Utopias support, says Paul-Michel Foucault, and that is what we can deduce from Marina Abramovic's Iconic Artworks. The House with the Ocean View is a living public installation, a kind of domestic island that a seminal artist places in a subdivision of rooms. Twelve days in three raised rooms, two rooms and a service, it becomes the setting for an experiential and apocalyptic vision of a daily routine, with rules and restrictions. The impossibility of going out, the proxemic enclosure of a current lockdown, manifests itself in the vertical connections, ladders of knives, the analogies with a confined public existence.

Keywords

distance, aesthetics of the look, images, drawing, utopia.

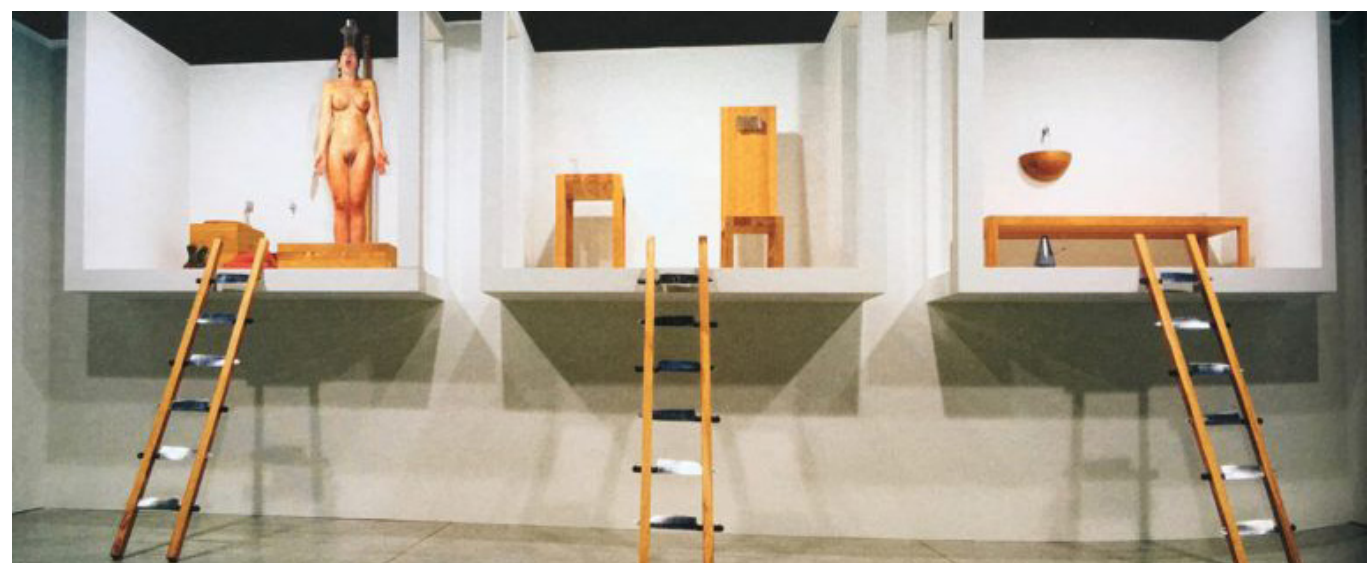


The distances do not separate the look from the observations that are associated with the diversity of the drawing by type of view, by exploration of the vision, by the position of a strategic point that is marked by the width of an angular view.

Environment, context and plane represent a perceptive relationship between a space of proximity and a space of distance in the evocation of a fixed point, a visual contact as a container of images.

The look that is defined belongs to a predetermined order of distances which, between location and displacement, prepare essential points of support, which establish a surroundings of support points placed between measure and overbalance.

First the look and then the word, in this sense, in the drawing, the width, the laterality and the distance, lead to imagine a multitude of alternative horizons.

The drawing is described between the rubbing of an instant and the distance of an image on the graphite landscape, which lives in occasional drawings. It stay like nature exhibited, between reinterpreted signs and themes that need to be traced.

Some distances to the definition of a 'drawing is correcting', or 'drawing is understanding', are considerations that appear when one feels that 'perceiving' is a way of examining and questioning oneself with the eyes.

After all, distance is the scene of the representation. It is what remains and is brought back into the presence when, often, in fact, the presence often disappeared. By drawing, in the absence of distance, we obtain the place where every presence becomes a reading of the measure, of the space, the observed form.

The diversity of a whole that divides two links with the terms 'distance' and 'Distance' represent everything that relates between us and our surroundings, something that becomes a variable interlude. That's what vision unites, between a chiselling and the immense.

Finctional hegemons.

Fig. I. Emilio Tadini, La camera da letto, 1993.

Fig. 2. Emilio Tadini, Oltremare, 1992.
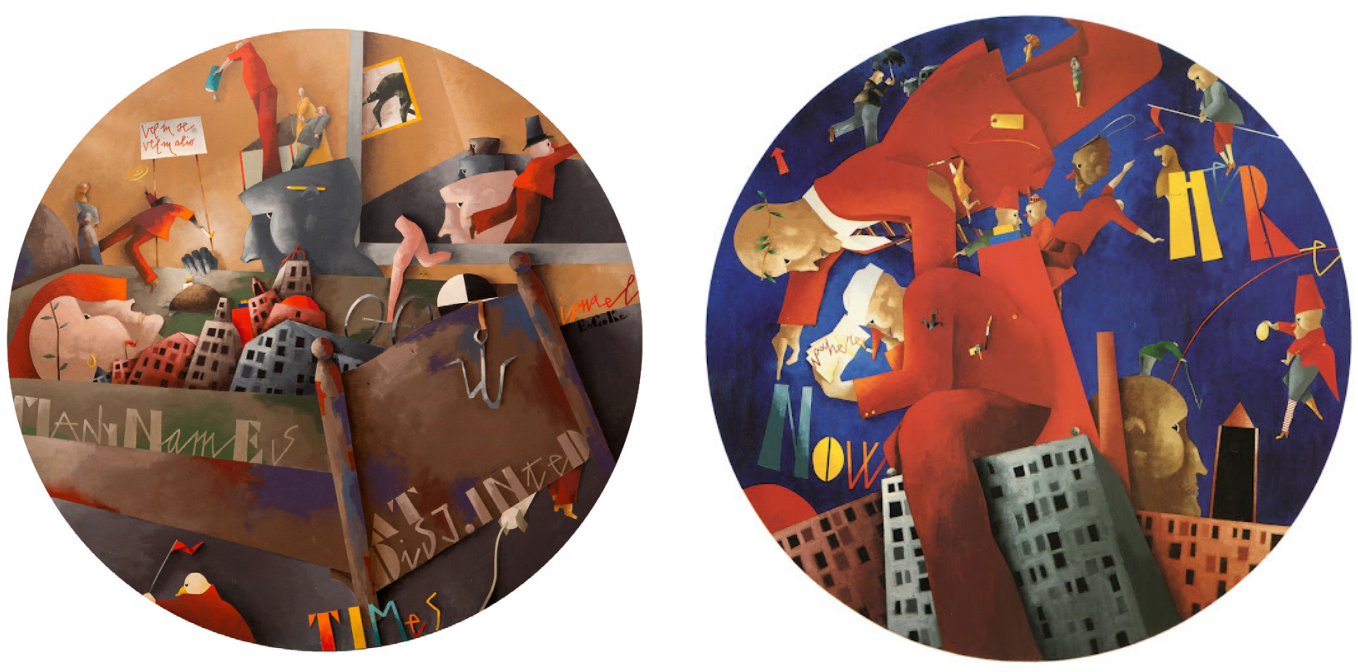

Utopias of distance

Il mondo a caso pone [Epicuro]

Distance as the value of an enigma unites us in the hypotheses and approximations that Emilio Tadini places in the evidence of a soft and ductile fragility in which representation, form and, perhaps, everything that we call 'aesthetic', set themselves the goal of measuring the distance [Tadini 1998, pp. I-9]. 
In a note of reflection, in the pathos of 'distance', Italo Calvino states that it is not distance, but the passion for the unheard-of that poses the concept of separateness. Everything that rests in distancing oneself, in the imagination between immanence and distance, as happens in a story: "I know it well -the old Qfwfq cried-you can't remember it but, but I can. We had her on top of us all the time, that enormous Moon" [Calvino 1965]. Calvino places distance in the dream description of a distant but not distant moon, in a metaliterary relationship of literary expressive conflict.

Among the lunar poets the concept of Distance moves from some verses of Ariosto who, in Astolfo of the Moon, after he understands the changing dimensions, puts the reversal of a the look: "Qui ebbe Astolfo doppia meraviglia: che quel paese appresso era si grande, il quale picciol tondo rassomiglia a noi che lo miriam da queste bande; e ch'aguzzar convegli ambe le ciglia, s'indi la terra e "I mar ch'intorno spande, discerner vuol; che non avendo luce, l'imagin lor poco alta si conduce" [Ariosto 1982, XXXV, 7I].

Fig. 3. Luca Ronconi, with the transposition by Edoardo Sanguineti, Orlando Furioso by Ludovico Ariosto, 1969.

Theatrical transposition of the Ariosto poem exhibited on 1969 at the Festival dei due Mondi in Spoleto.

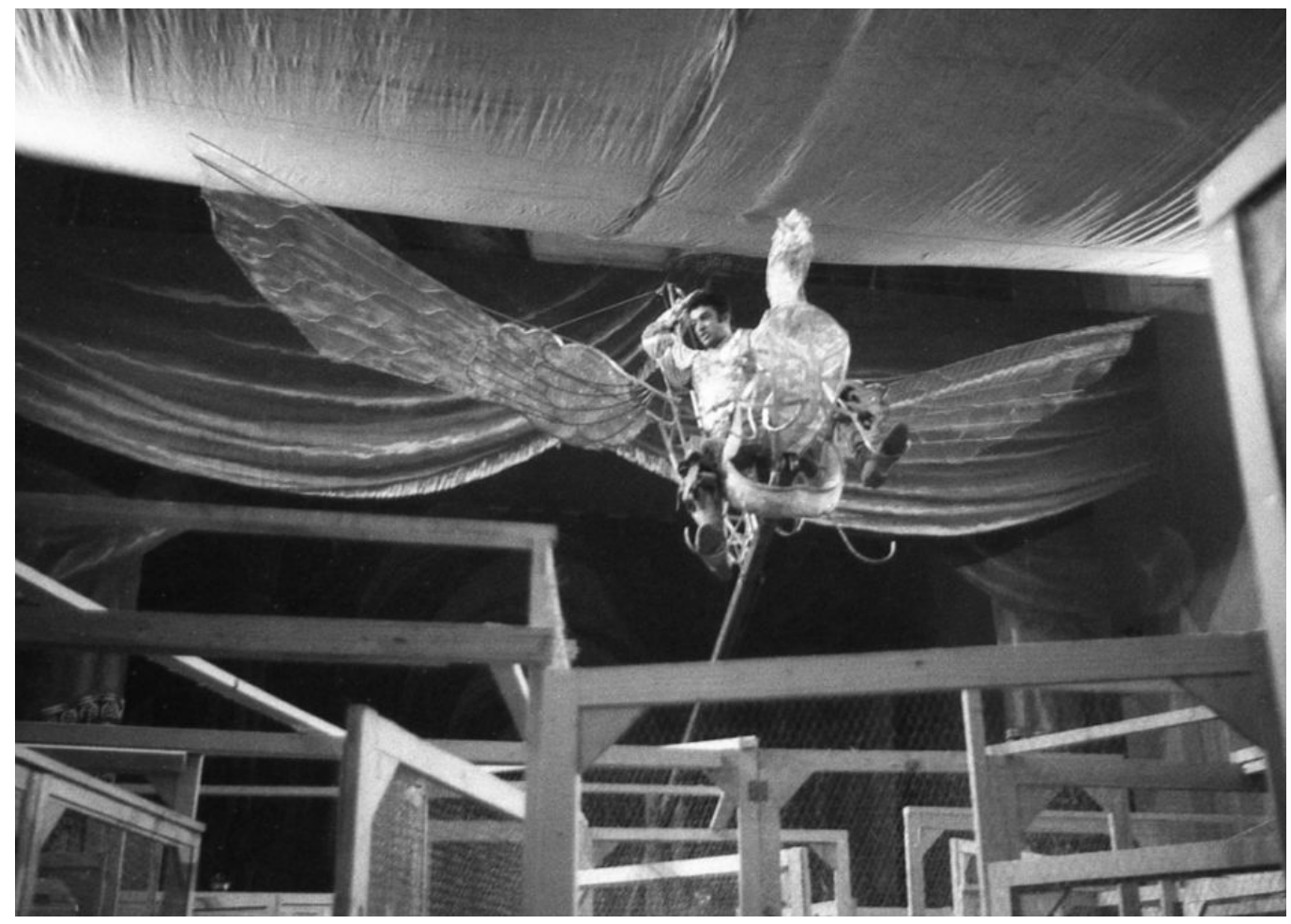

Between the moon and the remote islands we can see the reversal of the distance that two planets assume by changing the observation point and the enigma of composing mysterious facies in the vision of a topos by replacing in the unknown points and letters of a watermark for abstract interpretation of an atlas.

The importance we attribuite to the distance of a 'lost drawing' belongs to Judith Schalansky's [Schalansky 2009] considerations, between islands and insular, she describes the wandering with the fingers on the atlas of the expanded sense of utopia, away from everything and everyone in an angular distance that places the cartographer in the place where the earth has no margins.

Not far from these utopias there is also the imaginative vision of retracing, in an immeasurable planetary context, obscure distances in Fra' Mauro's tales of places by who, in the meditations of a cartographer, traces the boundaries land we have never seen.

From the stories of explorers, merchants, missionaries and pilgrims in distant lands, he undertakes, on parchment, through the imagination an ideal and subjective representation of an inspiration of unexpected questions in the dream of representing the world [Cowan 1998]. 
Fig. 4. Judith Schalansky, Atlante delle Isole remote. Cinquanta isole dove non sono mai stata e mai andrò, 2013.
Fig. 5. Fra Mauro, Mappamondo XV secolo, I 450 c. (detail) Marciana, Venezia).

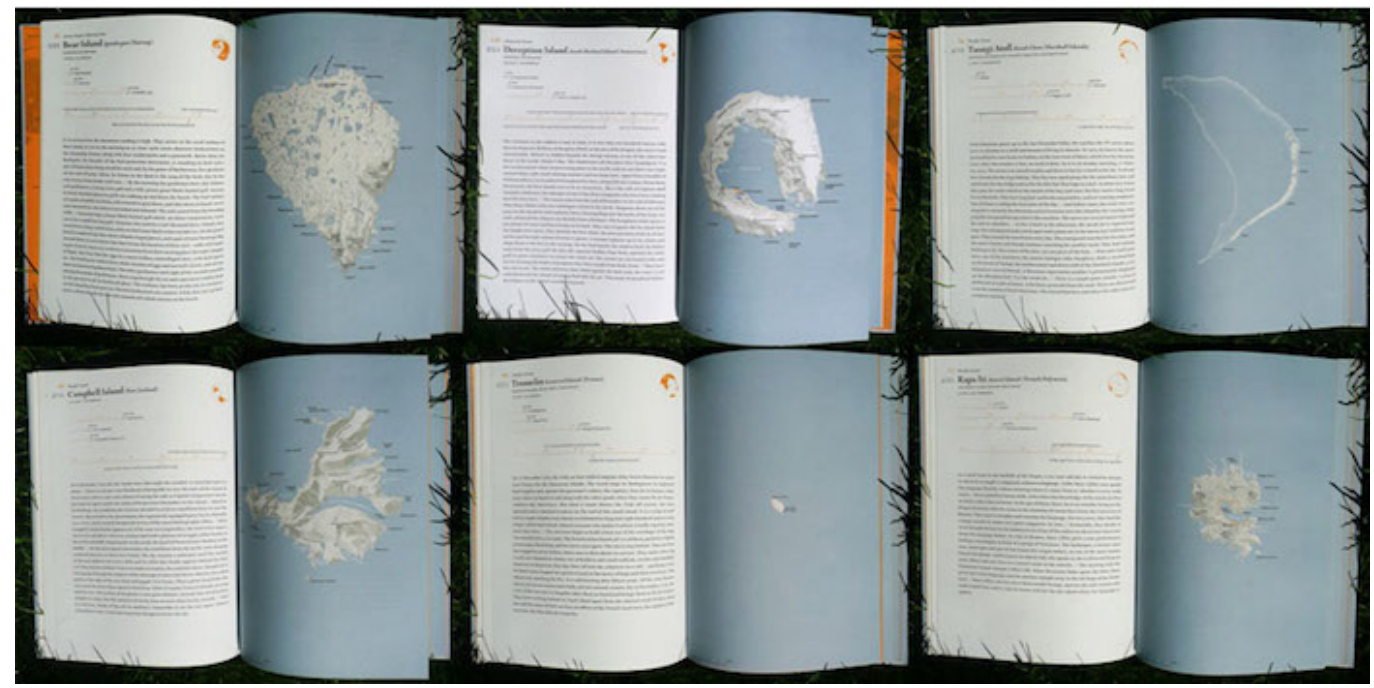

Other trajectories of distance, between stories and utopia, are the collage-drawings [Baglivo $2014]$ of an conceptual imaginary, a singular vision of timeless distances in encroachments, montages and mutations in the representation of an introspective aspect of a circular rewriting, between the monument and the graft.

And even John Berger, affirms that drawing is a way of investigating [Berger $201 \mathrm{I}$ ], it is the condition that appears among the found pages of a notebook, attributed to the Dutch philosopher Baruch Spinoza, called Bento, who noted that there is the sense of things i seeing through another's eyes.

The distance that is examined in Bento's notebook refers to the act of looking that in every "simulation drawing" appears the distance of a creative process between reality and imagination. In the act of looking, of questioning the eyes, we have almost become interchangeable. It must be because we both know where and to what the practice of drawing can lead and in the tout se tient, everything adapts "by drawing parts yourself, but the effort is to become what you are looking at. To grasp the connection with the thing in front of you and those around you, which are not seen in a form of manual contemplation" [Berger 20I I].

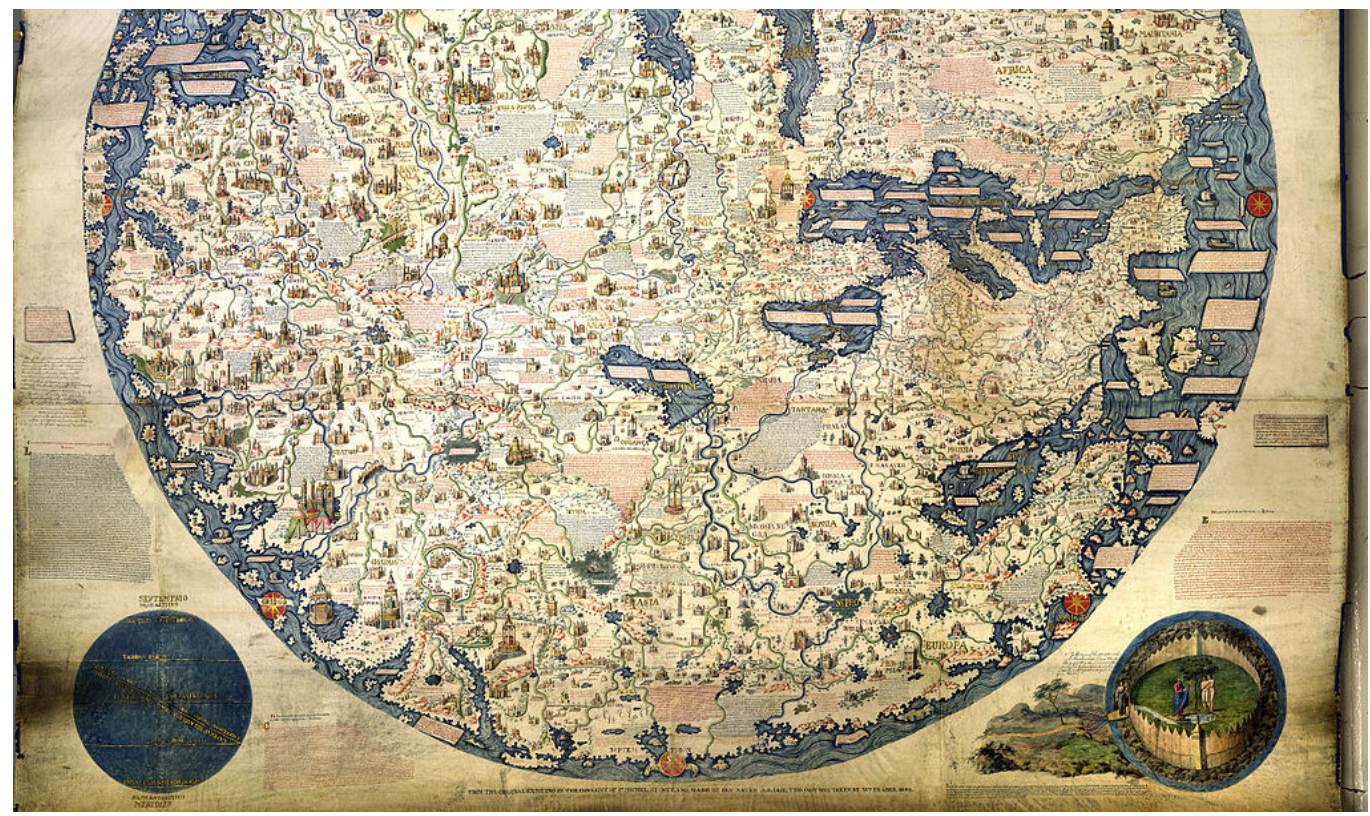




\section{Utopias of separation}

Utopia is an ethical drawing, far from rediscovering an "island that admits passion and rejects illusions" [Overton 20 I8].

Among the aspects of a supportive utopia there is the experience of Soul City, North Carolina, from the utopian construction to prison city, which is not about inspirational history, but essentially a "Negro City", a city that was never born. The ideal distance that makes use of a broken dream, a metaphor for a land of men who are free to experience the disappointment of the last utopia of detachment for the blacks of America is the becoming of the outcasts. What remains is the distance of an attempt to find a possible integration that is vanished for "Soul City: race, equality, and the lost dream of an American utopia" [Grosso 202 I].

The ocular distance of an utopia also appears between dystrophies and infirmities, in pathologies of darkness or diversity, and it is what is made up of stanzas. It is about Dippold's story, poems and confessions in the form of an epitaph [Lee Master 1943].

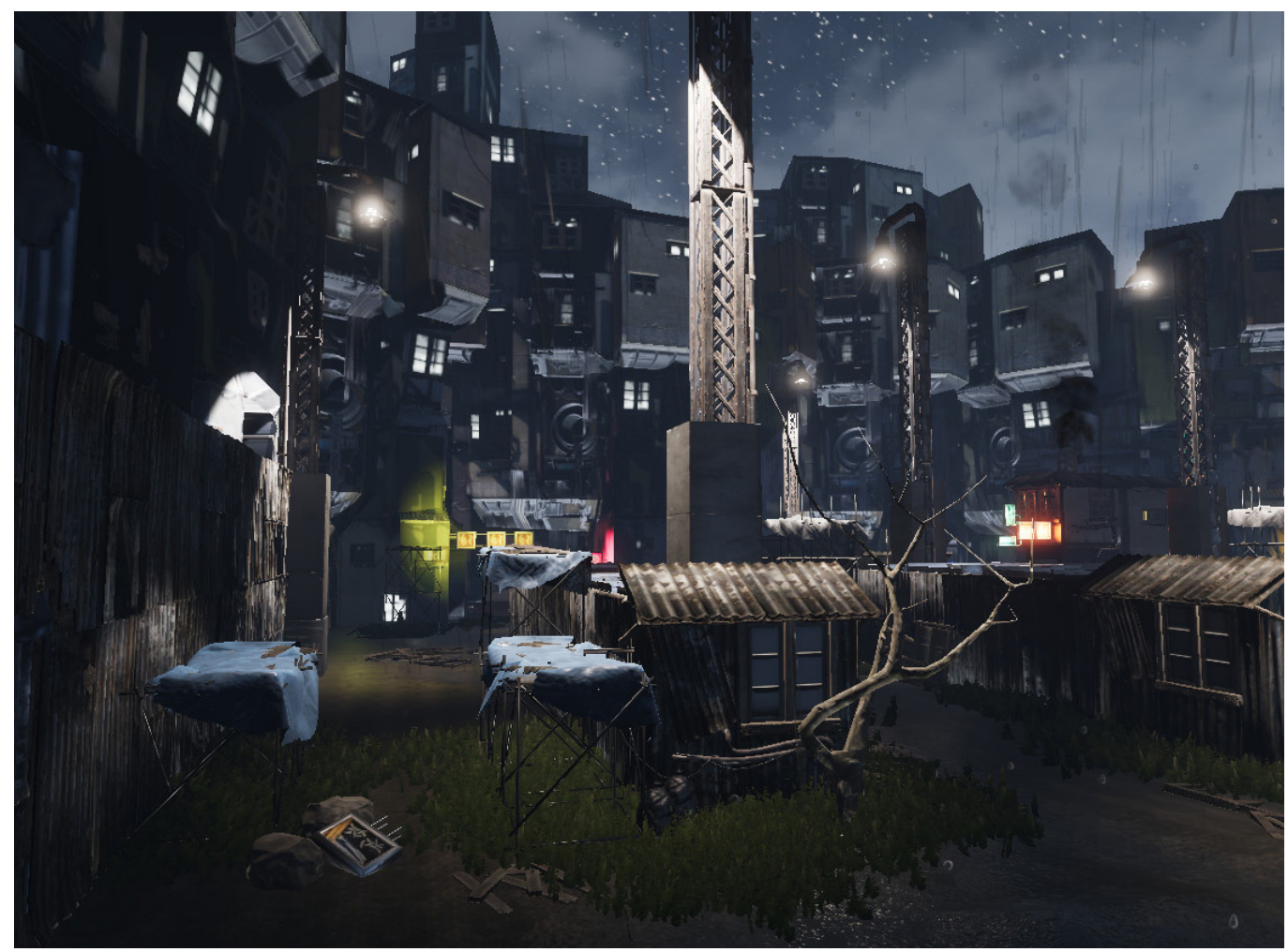

In the story of an optician who, in the idea of optimizing the distance is tired of simpy showing customers what is around them, and wants to make special glasses that allow to see beyond reality. Here are some verses that written Fabrizio De André, who recomposes the trace of a fragment in "Daltonici, presbiti, mendicanti di vista il mercante di luce, il vostro oculista, ora vuole soltanto clienti speciali che non sanno che farne di occhi normali. Non più ottico ma spacciatore di lenti per improvvisare occhi contenti, perché le pupille abituate a copiare invertino i mondi su quali guardare. Seguite con me questi occhi sognare, fuggire dall'orbita e non voler ritornare" [De Andrè 197I].

After all, distance is precisely the light that transforms the world into a toy. 
Movement can be recognized in stillness and it is the connection employed by Marina Abramovic exerts, at the MoMA in NY in 2010 , where constant distance finds less space to go elsewhere. A performance that combines the horizontal lines of the look of a visual dialogue of over 750,000 people in the invariable length which can be found in a silent relationship of communicating. Extending the space in an endless double line in the 736 hours of a unique presence and stable distance of connecting, touching the extreme, in that flow of energy that no longer needs anything.

Looks through looks are the sensations that belong to the same immaterial distance, on an invisible thread, which through the works describes the participation of those who are "observed". The canvases contain 'iconographic traps' that outline the informal aspect of the distance between the painting and the observer [Corgnati $20 \mathrm{l} \mathrm{I].} \mathrm{A} \mathrm{system} \mathrm{of} \mathrm{inter-}$ nal looks placed in the paintings of the characters that look at the relation of a visibility of the observer and the one who is observed on the distance of an artifice of looking in order to be looked between the gazes of the frames on the opposite observer and the framing of the subject in thematic implications.

The monuments look at us from above and everything that belongs to an inclined perception of the gaze, as Sigmund Freud states "the dominant sensation, the first impact with the statue, concerns the sense of immobility which is followed by the perception of the fixity of the gaze of the stone eye. If the statues are more than one, an intertwining of looks on unpredictable trajectories is established. [Barucchello 2003]. The stony, marble and wooden gaze reconstructs the perceptive immobility described by Andrei Arsenyevich Tarkowskij of 'sculpting time' [Tarkovskij 2002] figures of a permanent residence in which the look intertwines stable orientations in the spatiality of a place in relation to the blindness of matter.

And in the awareness of having 'big eyes', there is an elastic vision in Margaret Keane, in a consolidated prerogative that concerns the look. In almost all the works, the characters have large, wide-open and perfectly circular eyes, which cover a considerable part of the face, introjecting the observer into a parallel world.

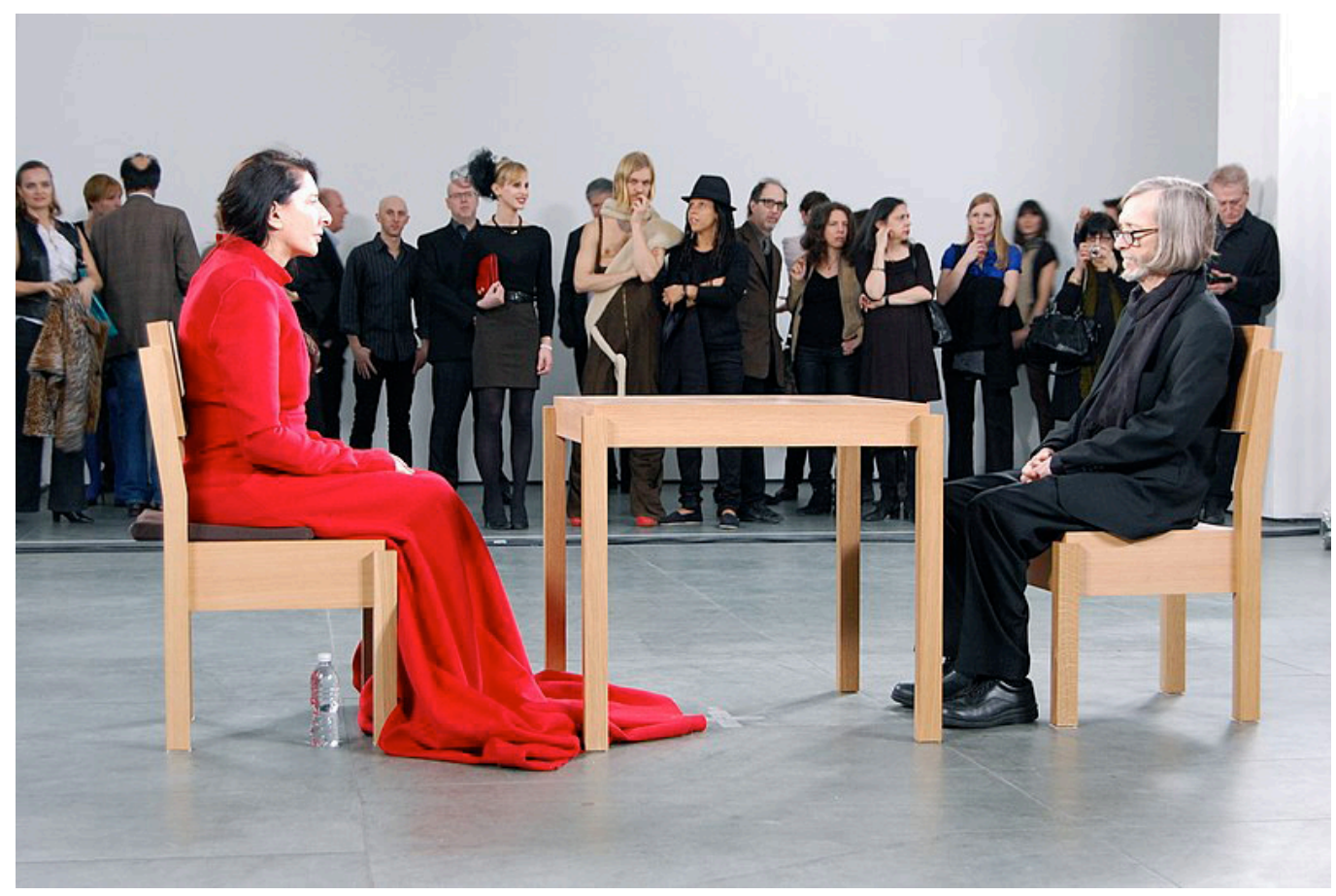


In Big Eyes, a movie directed by Tim Burton in 2014, present the inverse distance that Margaret Keane expresses in the portraits of big-eyed children, in which the figures convey the measure of the gaze and the big eyes express the inner distance of a wide visual dialogue.

Fig. 7. Margareth Keane, Big Eyes, 1963.

Fig. 8. Margaret Keane, Big Eyes, 1981.
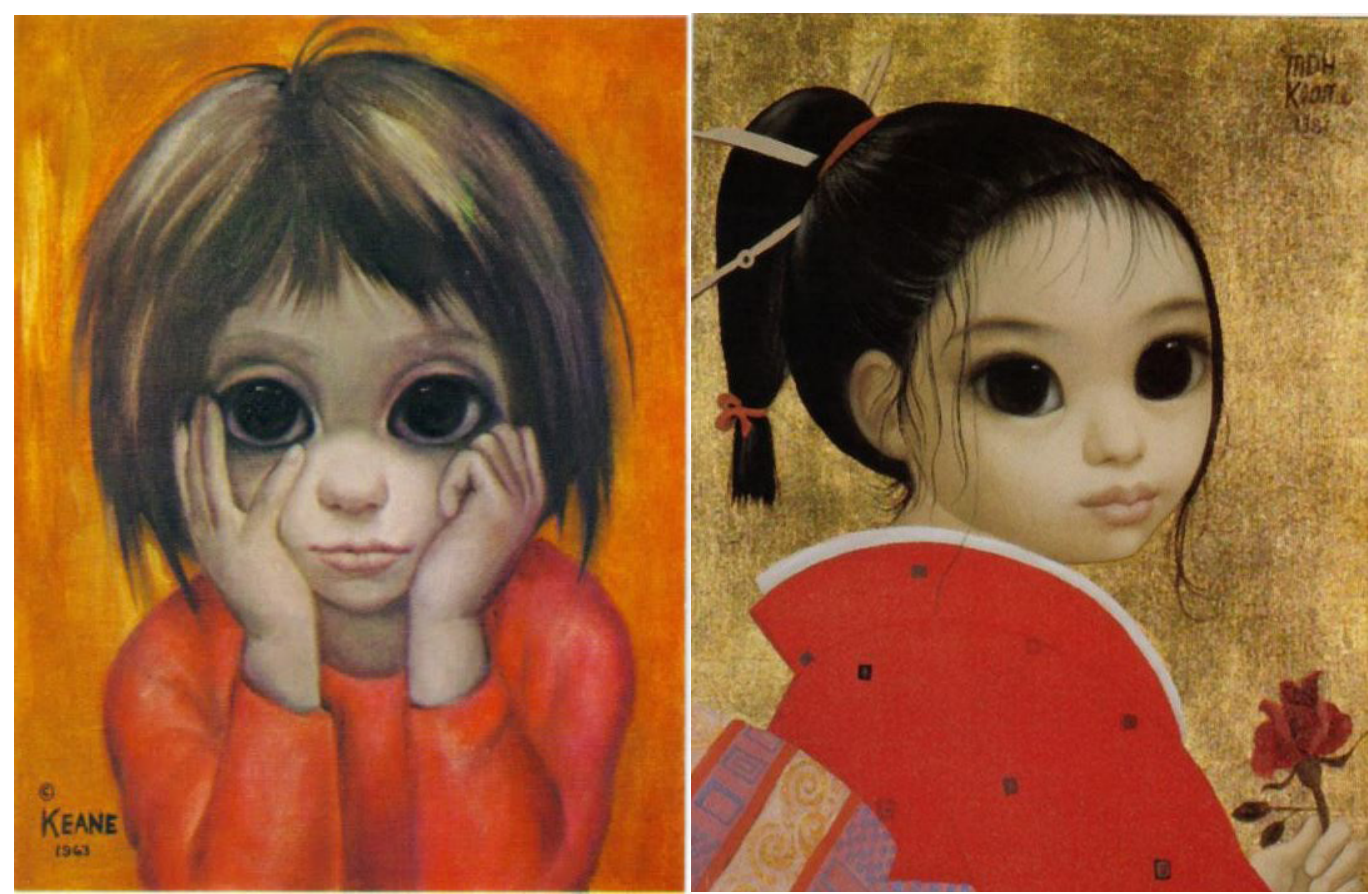

\section{Conclusions}

Il prossimo è distanza sullo stesso piano

[Emilio Tadini]

Ambiguity and disclosure, between one pole and the another, between proximity and distance, at the limit of every look there is a relationship of proximity that becomes a relationship of balance.

A substantial purpose is identified in the attempt to argue a discretized display form, by points, which correspond to the denomination of the interlocutory 'maps' in which the distance can only present itself as a new image of reality.

The space, therefore, becomes the representation of meeting between what appears and the shared look, a living in the strangeness of excess imaginaries that concern a relationship in the unity of closeness and distance.

In this context, across borders, the phenomena of the arrival and appearance of migratory displacements can be considered. A geography of the sequential look that tries to understand the complexity of dynamic space, flows of different nature, multidimensional relationships of continuous vision to identify, recompose, transcribe signs of a logic of reduction in looking grading and composing the lines of classification and meanings of the signs that connote human mobility with the role of the image of 'visual thought' and 'lost looks'.

For this purpose, other human migration maps are composed on a 'continuous look', determining what alludes to 'difficult geographies' of distance and neutral places and the 'hospitable look'. Spaces of coexistence in distance are dystopian visions of virtuous behavior, forced temporary changes of being restricted, with social distancing with spaces of countertrend. 
A 'look of mutation' towards a search for dispersion is that of disorientation that appears in the landscape of uncertainty, a fragile suspension in maintaining the distance of a Distance, a form of habit of ocular relativism.

The screen contracts diluted space as a form of social communication, vision is an exception to contagion, an ideal state of separation, a pervasive perception of distance.

Perception has the contagion of a stable place to grasp the absolute, through sensitive forms in which the gaze becomes the rubric of what appears to us and the distrust of founding the vision of an intus legere.

Reading the distance put connectography in the general vision together of images, to meet our gaze between a virtual space and the 'real' extension, in the perception of the infosphere of a boundless context.

Basically, as Emilio Tadini states, between immense distances and minimum distances, each distance can be represented by a line segment, that can be measurable as it is limited by two points.

\section{References}

Akers M. (20|4). Marina Abramovic. The artist is present. Milano: Feltrinelli.

Ariosto L. (1982). Orlando Furioso. Milano: BUR.

Baglivo C. (20|4). Disegni corsari. Melfi: Libria.

Barucchello G. (2003). Cosa guardano le statue. Ravenna: Danilo Montanari.

Berger J. (20 I I). II taccuino di Bento. Vicenza: Neri Pozza.

Calvino I. (1965). Le Cosmicomiche. Torino: Einaudi.

Corgnati M. (20 I I). I quadri che ci guardano. Opere in dialogo. Bologna: Editrice Compositori.

Cowan J. (1998). Il sogno di disegnare il mondo le meditazioni di fra Mauro cartografo alla corte di Venezia. Milano: Rizzoli.

De Andrè F. (1971). Non al denaro, non all'amore né al cielo. Milano: Dischi Ricordi.

Grosso L. (202I). II sogno spezzato. Quel che resta di un'utopia. Soul City, la città dei adesso è soltanto una prigione. In L'Espresso n. 15, Roma 4 aprile 2021.

Lee Master E. ( 1943). Antologia di Spoon River (trad. Pivano F.). Torino: Einaudi.

Overton T., Nadotti M. (a cura di). (20 I 8). John Berger. Ritratti. Milano: il Saggiatore.

Schalansky J. (2009). Atlante delle isole remote. Cinquanta isole dove non sono mai stata e mai andrò. Milano: Bompiani.

Tadini E. (1998). La distanza.Torino: Einaudi.

Tarkovskij A. (2002). Scolpire il tempo. Milano: Ubulibri.

\footnotetext{
Authors

Rosario Giovanni Brandolino, Università degli Studi Mediterranea di Reggio Calabria, gianni.brandolino@gmail.com Paola Raffa, Università degli Studi Mediterranea di Reggio Calabria, paola.raffa@unirc.it

To cite this chapter. Brandolino Rosario Giovanni, Raffa Paola (202I). L'ultra-distanza e l'epifenomeno della finitezza, tra distanza e Distanza/Ultra-distance and the epiphenomenon of finitude, between distance and Distance. In Arena A., Arena M., Mediati D., Raffa P. (a cura di). Connettere. Un disegno per annodare e tessere. Linguaggi Distanze Tecnologie. Atti del $42^{\circ}$ Convegno Internazionale dei Docenti delle Discipline della Rappresentazione/Connecting. Drawing for weaving relationship. Languages Distances Technologies. Proceedings of the $42^{\text {th }}$ International Conference of Representation Disciplines Teachers. Milano: FrancoAngeli, pp. 1 38 | - 1396.
} 